\title{
Self-Determination of Indigenous Peoples in Greenland: A Comparison with The Orang Asli in Peninsular Malaysia
}

\author{
Hashimah Abdul Halim \\ ROHAIDA NORDIN
}

\begin{abstract}
For many years, the indigenous peoples had been experiencing various acts of marginalisation and discrimination. However, to this day, the definitions and rights of the indigenous peoples in certain jurisdictions are still left ambiguous. These rights includes the right to self-determination which, on the surface, is linked to freedom to choose political status and cultural or economical development and can be considered as one of the vital rights for indigenous peoples as it allows the community to decide on various aspects of their lives. Looking beyond that, this concept can be further classified into external and internal self-determination and each country may adopt a different approach to this right. As Greenland has a relatively higher population of indigenous peoples, the laws and regulations on indigenous peoples can be distinct. Therefore, this study examines the availability of self-determination policies and possible issues on it's implementation in Greenland in comparison to the rights of the Orang Asli in Peninsular Malaysia. By using critical legal analysis, this study provides an insight to the exercise of self-determination rights of the indigenous peoples in other jurisdiction and the relevancy of the same right in Malaysia which can help to identify certain aspects to be improved on in the existing national indigenous peoples' rights laws.
\end{abstract}

Keywords: Self-Determination; Indigenous peoples; Self-Government; Greenland; Malaysia

\section{INTRODUCTION}

To the general public, the meaning of "indigenous peoples" are often synonymous with the term "original peoples of the land" or "aborigines". This perception is not incorrect but is insufficient to be legally referred. A proper formal definition of indigenous peoples is significant to appropriately identify the population and the rights that entails with it. Presently, it seems that there is yet to be one standardised definition that is accepted by all countries and scholars. Despite so, the definition given by Jose Martinez Cobo, the first United Nations Special Rapporteur in regards to discrimination against indigenous population is among the most generally accepted definitions. ${ }^{1}$ According to Martinez Cobo, indigenous peoples are

\footnotetext{
“... those which, having a historical continuity_with pre-invasion and pre-colonial societies that developed on their territories, consider themselves_distinct from other sectors of the societies now prevailing on those territories, or parts of them. They form at present non-dominant sectors of society and are determined to preserve, develop and transmit to future generations their ancestral territories, and their ethnic identity, as the basis of their continued existence as peoples, in accordance with their own cultural patterns, social institutions and legal system."2
}

Generally, it can be seen that there are several main criterias listed in the definition i.e. indigenous peoples have experienced historical events of invasion or colonisation by other parties, identifies that they are distinct from other groups of the national society, is presently having a non-dominant status in the national society and they are determined to preserve their ancestral territories and identity.

In the same report by Martinez Cobo, it was also mention that on an individual basis, an indigenous person can also be those who belongs to an indigenous population through self-identification and this fact is recognised and accepted by the members of the population. ${ }^{3}$ The right to self identification by the indigenous peoples is a starting point to give them the liberty to choose to be a part of the community but this may not be the only matter that the indigenous peoples would like to freely decide on. As every individual or group of peoples makes different choices in life, the right to selfdetermination is crucial to not restrict their free will. This right is not a foreign concept and in fact, it can be seen in several international instruments. Article 1 of the International Covenant of Civil and Political Rights (ICCPR) states that all peoples have the right 
to self-determination in which they can determine their political status and pursue economic, social and cultural development freely. ${ }^{4}$ The definition of "peoples" under the ICCPR, however, is not specific to indigenous peoples. There are several discussions that are not only confined to the meaning of "peoples" under the ICCPR but also to the extent of the self-determination rights provided and whether it can amount to the right to have an independent state. In this regard, an example can be seen through the opinion of Daes stating that the right of secession should only be applicable to people who are still subjected to "subjugation", "exploitation" and "domination" from foreign or external forces. ${ }^{5}$ Under this classification, it means that not all indigenous populations will be covered under "people" in the ICCPR for right to independent statehood especially when colonisation is less applicable in the present setting.

Additionally, not all countries ratified/acceded to the applicable international treaty making ICCPR not binding. On the bright side however, there are specific provisions under international law on the self-determination rights of the indigenous peoples. These are seen in the United Nations Declaration of Indigenous Peoples Rights (UNDRIP) where Article 3 outlines that the indigenous peoples possess the right to self-determination and Article 4 further states the exercise of this right is in regards to autonomy in their internal or local affairs. ${ }^{6}$ It is undeniable that the UNDRIP recognises a certain degree of self-determination rights of the indigenous peoples but it is important to note that this instrument is a declaration and therefore does not have the binding power like an international treaty. Thus, in this aspect, domestic laws can be relevant to determine the extent of the right of self-determination given to the indigenous peoples in the country.

Therefore, this study examines the availability of self-determination policies and possible issues on it's implementation in Greenland in comparison to the rights of the Orang Asli in Peninsular Malaysia. By using critical legal analysis, this study provides an insight to the exercise of self-determination rights of the indigenous peoples in other jurisdiction and the relevancy of the same right in Malaysia which can help to identify certain aspects to be improved on in the existing national indigenous peoples' rights laws.

\section{INDIGENOUS PEOPLES IN GREENLAND}

\section{IDENTIFICATION OF INDIGENOUS PEOPLES IN GREENLAND}

Greenland is a self governing region which became a part of Denmark since 1953. It can also be known as Kalaalit Nunaat which means "Greenlanders' land" by its people. ${ }^{7}$ The indigenous peoples in Greenland are known as Greenlandic Inuit and make up the majority of the population. As of July 2019 , it is said that the indigenous population in Greenland was up to $88 \% .^{8}$ This is different from the population of indigenous peoples in many countries including Malaysia where they are the minorities. The Greenlandic Inuit is recognised by the government of Denmark through it's declaration that only the original inhabitants of Greenland or Inuit falls under the ILO Convention on Indigenous and Tribal Peoples No. 169 (ILO Convention 169), ${ }^{9}$ as stated in Article 1:

“(b) peoples in independent countries who are regarded as indigenous on account of their descent from the populations which inhabited the country, or a geographical region to which the country belongs, at the time of conquest or colonisation or the establishment of present state boundaries and who, irrespective of their legal status, retain some or all of their own social, economic, cultural and political institutions."

It was also mentioned that the classification of "peoples" under Article 14 of ILO Convention 169 also refers to the Inuits in Greenland ${ }^{10}$ :

"The rights of ownership and possession of the peoples concerned over the lands which they traditionally occupy shall be recognised. In addition, measures shall be taken in appropriate cases to safeguard the right of the peoples concerned to use lands not exclusively occupied by them, but to which they have traditionally had access for their subsistence and traditional activities. Particular attention shall be paid to the situation of nomadic peoples and shifting cultivators in this respect."

Although there can be many subgroups or cultures in the Greenland, the indigenous peoples are known collectively as Inuit. ${ }^{11}$ This view can be reflective in the decision of the Danish Supreme Court [2004] 98(3) AJIL 572 concerning the relocation of some families from their settlement in Thule (northern part of Greenland). ${ }^{12}$ The "Thule tribe" was awarded damages for the serious interference and relocation but was denied the claim 
to return to the land. ${ }^{13}$ In this case, the court also mentioned that the "Thule tribe" is a part of the Inuit population in Greenland and is not a distinct indigenous population of its own. ${ }^{14}$ This position is seen to be similar in Peninsular Malaysia in the way that the different sub-groups of indigenous population are also collectively known as Orang Asli. However, looking into the constitution of the country, there are some distinctions made to the indigenous peoples in the east and west states of Malaysia. The Federal Constitution of Malaysia defines "aborigine" as the aborigines of the Peninsular Malaysia and "natives" as the indigenous races of Sabah and Sarawak. ${ }^{15}$ The constitution also defines individuals that are "natives" of Sabah and Sarawak e.g. a citizen that belongs to one of the indigenous races listed ${ }^{16}$ and can include mixed blood from those races in Sarawak and a citizen who is the child or grandchild of a person from an indigenous race in Sabah. ${ }^{17}$ For the Peninsular of Malaysia, legislations such as the Aboriginal peoples Act 1954 (only applicable to Peninsular Malaysia) further defines on the individuals that are considered as aborigines. Examples of several factors taken into consideration are, individuals with an aboriginal male parent, adopted by the aboriginal race and brought up as an aborigine and children of the union between an aboriginal female with male of other races..$^{18}$ In comparison, there seems to be a lack of specific legislation for indigenous peoples and formal definition for the Inuits in Denmark's constitution. Likewise, the Greenland SelfGovernment Act of 2009 which is a framework to prepare the region to be a self-governing region and recognises the self-determination right of the people of the region, did not provide for the definition and made reference to the "peoples of Greenland" in general. Based on several literatures, the peoples in Greenland are generally classified into those born in Greenland, which are roughly considered as native Greenlanders or Inuit and those born outside of Greenland. ${ }^{19}$ Despite this, several characteristics can still distinguish an Inuit from a non-Inuit such as language, culture and self identification. ${ }^{20}$

\section{THE INUIT POPULATION IN GREENLAND}

The term "Inuit" which means "peoples", is a term that is often associated with the indigenous population in several territories such as Greenland,
Canada and the United States (Alaska). The history of the settlement of Inuit groups at the coastal areas of Greenland can be traced back to more than thousands of years ago. ${ }^{21}$ The Inuit Thule population, believed to have migrated from the Alaskan region, was estimated to have arrived at Greenland around $1300 \mathrm{AD}^{22}$ Although there were already other settlements in Greenland at that time such as the Norse and Dorset, eventually, these populations started to diminish while the Thules expanded along the coastal areas. ${ }^{23}$ Most of the Inuits today are said to have ancestral links to the Thule peoples. ${ }^{24}$

The Inuits in Greenland can be divided into three major groups namely, the majority Kalaalit ${ }^{25}$ at the west of Greenland that speaks Kalaallisut, the Tunumiit at east of Greenland that speaks Tunumiit Oraasiat and the Inughuit at the north of Greenland that speaks Inuktun. ${ }^{26}$ Their language can then be divided into different dialects. Although it can be seen that there is linguistic diversity in Greenland, the official language of the self-governing region as stated in the Self-Government Act 2009 is Kalaallisut.

Other interesting aspects of their culture includes the activities of fishing and subsistence hunting particularly marine mammals which have existed in their community for a long time. This may be due to the fact that the low temperature and climate of some parts of Greenland are not fitting for agriculture. The culture of hunting is so significant in the Inuit community that it was also mentioned in the previous Greenland Home Rule Act 1978, the Act for a framework to manage their affairs as a home rule authority. It was stated under the Schedule of the 1978 Home Rule Act that Greenland was given jurisdiction in the matter of "fishing in the territory, hunting, agriculture and reindeer breeding". ${ }^{27}$ One example of their hunting activities involves whale and seal hunting which can be one of the contentious topics to be discussed on international level.

Relatively, although the indigenous population in Malaysia are the minorities, the three main groups of the Orang Asli (defined as "aborigines") in West Malaysia are Negrito, Proto-Malay and Senoi, which can be divided into up to 18 sub-groups and comes from various regions mainly around Asia. ${ }^{28}$ This number of sub-groups can further increase with the inclusion of the indigenous community in Sabah and Sarawak (East Malaysia). Naturally, due to the warmer climate and geographical locations, the 
livelihood culture of indigenous peoples in Malaysia can mainly include agriculture and foraging for forest resources like food and medicinal plants besides fishing and hunting.

\section{SELF DETERMINATION LAW FOR INDIGENOUS PEOPLES IN GREENLAND}

\section{BACKGROUND ON GREENLAND'S SELF-GOVERNING STATUS}

The link between Greenland and Denmark can be traced back to a long line of history. Greenland was a part of Norway when the union between Norway and Denmark was established in the 14th century. ${ }^{29}$ This position continues until the 1814's Kiel Peace Treaty. Through this agreement, Norway was ceded to Sweden but Greenland remained as a part of Denmark. ${ }^{30}$ Greenland then experienced another shift of status in the 1900s. In 1953, it's status as the colony of Denmark was abolished and integrated into the realm through its constitution. ${ }^{31}$ This fact was also acknowledged by the UN General Assembly in 1954 in their resolution that Greenland was removed from the list of non-self governing territories. ${ }^{32}$ The Denmark's constitution of 1953 not only included Greenland and Faroe islands into the Danish realm but also gave them two seats each at the Parliament of Denmark in its section $28 .{ }^{33}$ Subsequently, Greenland continues to witness a gradual increase of autonomy power and political independence. The two significant events linked to this were the Home Rule and Self-Government arrangements made in 1979 and 2009.34

In 1975, the Minister of Greenland established a committee called the Commission on Home Rule in Greenland which consequently submitted a report proposing for a Home Rule Act. ${ }^{35}$ Denmark then adopted the proposed statute. In 1979, a referendum was held for the legislation resulting to the majority of Greenland voting in favour of it leading to the arrangement of the Home Rule in Greenland. ${ }^{36}$ This Home Rule Act transferred some of the legislative and executive powers vested by the Denmark government to the home rule authority i.e. Greenland. The relevant fields were listed in the Schedule of the Act and include but not limited to matters such as organisation of local government, taxes, fishing in the territory, hunting, agriculture and reindeer breeding, country planning, education and health services. ${ }^{37}$ The Act also witnessed the establishment of Greenland's legislative assembly called the "Landsting" with its four year-term members chosen through elections and the administration of Greenland headed by an executive "Landsstyre" who is to be elected by the Landsting. ${ }^{38}$ In matters relating to foreign affairs however, the power is still in the jurisdiction of Denmark. ${ }^{39}$

This home rule arrangement ended in 2009 after another referendum was held in November 2008 where more than 70 percent of the population of Greenland voted in favour of the Self Government Act drafted by the home rule authorities. ${ }^{40}$ According to the next Self-Government Act 2009, the Home Rule Act 1979 is then repealed in exception to Section 8 of the 1979 Act on the fundamental rights of the people of Greenland on its natural resources until the self-government takes over the mineral resources area. ${ }^{41}$

\section{THE CURRENT SELF-GOVERNING LAW IN GREENLAND}

In 2009, the Greenland Self-Government Act came into force replacing the previous 1979 Home Rule Act. This Act brings recognition to Greenlanders as peoples under international law with the right to self-determination and Greenlandic being the national language of Greenland. ${ }^{42}$ It provides a clearer structure and wider powers to Greenland for the establishment of their own self-government.

This new act clearly listed the organs of the government comprising the Greenland Parliament (Inatsisartut), the Executives (Naalakkersuisut) and the Judiciary with its powers vested on the courts. ${ }^{43}$ It also further extends the jurisdiction of the self-government to several other matters including establishment of courts and legal services under the Act's Schedule. According to Chapter 4 of this Act, Greenland may now act in international affairs and conclude agreements but subject to several terms such as informing the government of Denmark on initiation, development and conclusion of the agreements. Besides that, the Act witnessed a new economic arrangement where the self-government will manage the finance of the matters falling under its responsibilities and the subsidy received from Denmark is set to be DKK 3,439.6 million but subject to reduction following the amount of revenue received from the mineral resources activities. ${ }^{44}$

Other significant changes on the SelfGovernment Act include the shift of responsibility on mineral resources activities in Greenland to the self-government authorities. This is significant because, due to the effect of climate change on it's landscape, the mineral resources in Greenland had 
been attracting investments from foreign firms and companies resulting in an increasing number of mineral exploration activities in the self-governing region..$^{45}$ The matter of mineral resources areas is listed in List II of the Schedule in pursuant to Chapter 2 of the Act which is one of the subject matter in which the jurisdiction is transferred to Greenland. The mineral resources areas as stated in the explanatory notes of the Act relates to "exploration for and exploration of mineral resources in Greenland" 46 therefore giving Greenland a degree of control over its own natural resources. In addition to that, the Act also outlines that the revenue from the mineral resource activities shall be accrued by the Greenland's self-government. ${ }^{47}$

Finally yet importantly, the Act also mentions Greenland's access to independence which will mark the start of its sovereignty on the territory. According to Chapter 8, this decision is to be taken by the peoples of Greenland and followed by the negotiations between Denmark and the Executives (Naalakkersuisut) with the perspective to introduce independence for Greenland. This agreement will require the consents of Greenland's Parliament (Inatsisartut) and Danish Parliament (Folketing) while endorsed by a referendum in Greenland. ${ }^{48}$ The exact wordings of the provisions are as stated below:

“21. (1) Decision regarding Greenland's independence shall be taken by the people of Greenland.

(2) If decision is taken pursuant to subsection (1), negotiations shall commence between the Government and Naalakkersuisut with a view to the introduction of independence for Greenland. (3) An agreement between Naalakkersuisut and the Government regarding the introduction of independence for Greenland shall be concluded with the consent of Inatsisartut and shall be endorsed by a referendum in Greenland. The agreement shall, furthermore, be concluded with the consent of the Folketing.

(4) Independence for Greenland shall imply that Greenland assumes sovereignty over the Greenland territory."

\section{SELF DETERMINATION OF INDIGENOUS PEOPLES UNDER THE SELF-GOVERNMENT ACT 2009}

Due to the provisions in the Act, this law is often associated with the principle of self-determination right of the indigenous peoples by the international community. To begin with, the preamble of the Act gives recognition to the peoples of Greenland as "peoples" under the international law with the right to self-determination and is considered as an equal partner to the Danish government. ${ }^{49}$ The term "peoples" under international law can be defined in many ways including to represent a group of peoples with common characteristics. An example is in the use of "peoples" to refer to the Greenland population in the Danish realm. ${ }^{50}$ There are several international laws giving acknowledgement to the right to self-determination of peoples including Article 1 of the International Covenant on Civil and Political Rights (ICCPR) although this recognition is not given specifically to the indigenous population in Greenland. Instead, it is given to the peoples of Greenland as a whole (territorial) and does not differentiate the ethnic or racial backgrounds of its citizens. ${ }^{51}$ This also means that the people of Greenland in general can be entitled to the right of self-determination under the ICCPR which includes the right to external self-determination or establishment of new states. However, it is important to note that the indigenous community or Inuit constitute the majority which is up to more than 80 percent of the population in Greenland.

It is a fact that the right to self-determination is recognised under the international law which include specific recognition given to the indigenous peoples under the UN Declaration on the Rights of Indigenous peoples (UNDRIP) where its Article 3 states that;

"Indigenous peoples have the right to self-determination. By virtue of that right they freely determine their political status and freely pursue their economic, social and cultural development."

However, the UNDRIP is a declaration and is not legally binding to it's parties. Treaties such as the ICCPR and ILO Conventions on the other hand can be legally binding but only when it is signed, ratified or acceded by the sovereign country. Fortunately, the ILO Convention 169 and ICCPR was ratified by Denmark.

Now, it is important to understand the meaning and types of self-determination to properly grasp the extent of ICCPR, UNDRIP and other international provisions. There are various definitions given to the term "self-determination" under international law but generally, it can be divided into internal selfdetermination and external self-determination. The meaning and extent of the two classifications varies according to scholars but generally, internal selfdetermination can refer to the right of the peoples to decide on their own social, political and economic system such as participation in processes of power while external self-determination is more associated with establishment of statehood or economical and political independence. ${ }^{52}$ Applying this, it can be seen that the self-determination referred to in UNDRIP is 
more on the exercise of internal self-determination. In fact, Article 4 of the UNDRIP provides that in exercising self-determination of the indigenous peoples, the right of self-government is in relation to the internal or local affairs. ${ }^{53}$ In addition, Article 46 states that;

"1. Nothing in this Declaration may be interpreted as implying for any State, peoples, group or person any right to engage in any activity or to perform any act contrary to the Charter of the United Nations or construed as authorizing or encouraging any action which would dismember or impair, totally or in part, the territorial integrity or political unity of sovereign and independent States."

Following these provisions, it seems that the self-determination right under the UNDRIP is more relevant to internal self-determination for indigenous peoples. ${ }^{54}$ Despite the fact, external selfdetermination can still be applicable when executed through mutual agreements and arrangements with the governing State. Looking at the example of Greenland, it is clear that some degree of selfdetermination rights exist but the question is on the extent of those rights. There are literatures that refer to the position in Greenland as having a high level for exercise of internal self-determination. ${ }^{55}$ This is made apparent by their ability to make their own laws in a number of prescribed areas. In fact, several legislations have been passed over the years including but not limited to Act on Preservation of Cultural Monuments 2007, Act on the Protection of Nature 2003 and the Mineral Resources Act 2010. On the aspect of external self-determination however, Greenland has yet to be a fully independent state but the endeavours towards it are not completely nonexistent.

Through the Home Rule Act and SelfGovernment Act, it can be seen that the introduction of self-governance is incorporated gradually into Greenland. Many aspects of Greenland's selfgovernment now resemble the composition of an independent state having authorities in the fundamental bodies such as the judiciary, legislative and executive. The establishment of the legislative and executive bodies in the Home Rule Act and SelfGovernment Act has enabled the self-government to enact its own laws and make decisions on matters relating to Greenland. Several ministries have also been established to manage it's affairs e.g. Ministry of Education, Culture, Research and Church, Ministry of Finance, Ministry of Health and Ministry of Mineral Resources. ${ }^{56}$ Besides that, Greenland's jurisdiction on it's mineral resources is also a significant point that shows a step forward to reduce its dependence on Denmark by having their own self-sustaining economy and gradually reducing the subsidies received from the Danish government. Furthermore, it also provides a prospect to the introduction of independence to Greenland in the Self-Government Act which can be a different state of affairs as compared to other regions such as Kurdistan where the communities' referendum for independence was deemed by the Supreme Federal Court of Iraq as unconstitutional. ${ }^{57}$

Additionally, external self-determination does not necessarily equals secession but can also include participation by way of representatives in international negotiations. ${ }^{58}$ The element relating to foreign affairs can be seen in Chapter 4 of the SelfGovernment Act where Greenland can negotiate and conclude international agreements provided that it exclusively concerns Greenland and falls within it's jurisdictions. Although it has not happened yet, the arrangement shows efforts to introduce independence to Greenland from the Danish realm.

In comparison, the position of self-determination right for the indigenous peoples i.e. Orang Asli in Malaysia and the Inuit in Greenland are very distinctive. Firstly, the Malaysian government has yet to ratify or accede to the ICCPR or the ILO Convention 169. In addition to that, currently, there is no self-governing law for the Orang Asli to establish their own autonomous state however, this may also be due to the communities' own preference to remain within the state. ${ }^{59}$ There are some aspects of internal self-determination seen in the Aboriginal Peoples Act 1954 although limited. This is in regards to control and decisions on several matters within their community however, it can be further restricted because many of the matters of the Orang Asli falls under the purview of the Department of Orang Asli Development (JAKOA) in Malaysia. For example, section 16 of the Act implies that the community can appoint their own headman but subject to the confirmation of the Minister. ${ }^{60}$ Furthermore, JAKOA is also given the authority to decide on whether an individual is an aborigine or not. ${ }^{61}$ This involvement of JAKOA in the Orang Asli's affairs is arguably still necessary nevertheless this is the current setting in Malaysia which may not be an ideal position for the right of self-determination or decision making of the Orang Asli especially when the top authorities in the department are not Orang Asli themselves.

In addition to this, generally, the Orang Asli is given the right to vote and form their political 
party. However, it is apparent that there is a scarcity of Orang Asli political parties in Malaysia which is most likely due to the non-dominant position of the indigenous community. ${ }^{62}$ This fact then led to the lack of representatives of Orang Asli in the Parliament and their involvement in law-making processes. There are also not many options for public participation by the Orang Asli in decision making. An example where the indigenous peoples are able to express their opinion is during the construction of the Environmental Impact Assessment (EIA) report ${ }^{63}$ However, there are no requirements for the Department of Environment to seek for their participation. ${ }^{64}$

\section{ISSUES ON THE SELF-DETERMINATION OF INDIGENOUS PEOPLES IN GREENLAND}

One material point is that the right of self-governance given to the peoples of Greenland is not exclusive to indigenous peoples but is seen collectively as the whole population of the autonomous region that has a majority of indigenous population. It is important to note that Greenland is not only home to the Inuits but also including a minority population of the nonInuits having Danish citizenship. Thus stating that the self-government in Greenland is an exercise of self-determination rights of the indigeous peoples can be arguable. Instead, it may be more relevant to state that this self-determination right is given to the population of Greenland as "people" under international law. This situation can relate to the case regarding East Timor that has a majority population of indigenous peoples which can be traced back to several origins including the Malay-Polynesian. ${ }^{65}$ When the region was colonised by Portugal, East Timor unilaterally declared independence from the coloniser in 1975 but was later invaded and was regarded by Indonesia as one of its territories before eventually becoming an independent state in $2002 .{ }^{66}$ This exercise of their right of self-determination was given in pursuant to their rights as "people" under international law although they have a majority population of indigenous peoples and was illustrated in the International Court of Justice case of East Timor (Portugal v Australia), 1995 ICJ 80, 120, where it states that:

"For the two Parties, the Territory of East Timor remains a non-self governing territory and its people has the right to selfdetermination."
Furthermore, there are several sub-groups and dialects in the Inuit community in Greenland. Not only that their rights can only be claimed collectively as Inuit irregardless of their divisions, the use of the Kalaallisut, the language of the majority at west of Greenland as the national language may not be a proper representation of the various sub-groups and tribes within the self-government. To make the matter worse, the other languages in Greenland i.e. Inuktun and Tunumiit oraasiat are considered to be "definitely endangered" by the United Nations Educational, Scientific and Cultural Organisation (UNESCO) which means that there are high possibilities that the children of the community no longer learn the language as their mother tongue at home. ${ }^{67}$

\section{CONCLUSION}

Many of the indigenous peoples in the world are facing challenges to exercise their right to selfdetermination even on matters relating to their own cultures and communities. These populations should be given the liberty to decide the governance of their own community if they choose to do so. This is to give rights to the indigenous peoples to establish their desired leadership and also ensure the survivability of many aspects of their cultures such as language and traditional knowledge.

The self-government rights of the peoples of Greenland is a good example of exercise of selfdetermination for indigenous peoples although it is not exclusively given to the Inuits. Many aspects of the Self-Government Act are still very relevant to the ethnic i.e. Inuits. For example, the self-government is able to practice Kalaallisut as the national language of Greenland. With most of the population being indigenous, it also means that the probabilities are higher to have the Inuits be involved in law-making processes in the Parliament. This shows that being the majority of the population in self-government Greenland can also relate to the development of the ethnic population.

This position or the right of self-government like Greenland may not be the preference of all indigenous communities in the world. Undeniably, there are indigenous peoples that would opt for a different level of exercise of self-determination right such as the self-governance of their own community within a state. However, this does not mean that this right should be negated under the international law. 
The indigenous peoples's self-determination right should still be available under international laws to provide the opportunity for the population to exercise these rights.

Relatively, since the Orang Asli population in Peninsular Malaysia are numerically distinctive from the indigenous population in Greenland, the exercise of the same right in Malaysia may face challenges for the time being including the preparedness of the community to establish their own self-ruling territory. In the aspect of their rights to internal selfgovernance, however, there may be areas that can be improved particularly in providing a higher level of liberties to the indigenous peoples to decide and control matters in their own community.

\section{ACKNOWLEDGEMENT}

The authors wish to thank Universiti Kebangsaan Malaysia for research grant GUP-2020-066 for financing this research work.

\section{NOTES}

1 Nordin, R., Rights of the indigenous peoples in Peninsular Malaysia: domestic and international perspectives, Penerbit Universiti Kebangsaan Malaysia, Bangi, 2018,pg 58.

2 Cobo, J. M., Study of the Problem of Discrimination Against Indigenous Populations: Final Report E/CN.4/ Sub.2/1986/7/Add.4. New York: United Nations, 1987,pg 29.

$3 \quad$ Ibid, pg 29, para 381.

4 The United Nations General Assembly, International Covenant on Civil and Political Rights. Treaty Series, 999, 171. Article 1, 1999.

5 Nordin, R. Rights of the indigenous peoples in Peninsular Malaysia: domestic and international perspectives, pg 67.

6 The United Nations General Assembly, United Nations Declaration on the Rights of Indigenous peoples (A/61/L.67 and Add.1), 2007.

7 Freeman, M. M., Endangered peoples of the Arctic: Struggles to survive and thrive, Greenwood Press, London, 2000, pg 167.

8 Edited by Mamo, D., The Indigenous world, (34th ed.), International Work Group for Indigenous Affairs (IWGIA), Copenhagen, 2020.

9 Ulfbeck, V., Møllmann, A., Mortensen, B. O., Responsibilities and liabilities for commercial activity in the Arctic: The example of Greenland. Milton Park, Abington, Oxon, United Kingdom, Routledge, Taylor \&amp; Francis Group, 2018..

10 REPRESENTATION (article 24) - DENMARK - C169 - 2001. (n.d.). Retrieved July 06, 2020, from https:// www.ilo.org/dyn/normlex/en/f? p = $1000 \% 3$ A 500 $12 \% 3$ A $0 \% 3$ A $\% 3$ ANO $\% 3$ A $50012 \% 3$ AP 50012 COMPLAINT PROCEDURE ID\%2CP50012 LANG CODE $\% 3 \mathrm{~A} 250 \overline{7} 219 \% 2 \mathrm{Cen} \% 3 \overline{\mathrm{ANO}}$
11 Cultural Survival. Observations on the State of Indigenous Human Rights in Denmark in Light of the UN Declaration on the Rights of Indigenous peoples Denmark, 2015.

12 Spiermann, O., Hingitaq 53, Qajutaq Petersen, and Others v. Prime Minister's Office (Qaanaaq Municipality and Greenland Home Rule Government Intervening in Support of the Appellants), The American Journal of International Law, 2004, 98(3), 572.

13 Holle, M. L., The Forced Relocation of Indigenous peoples in Greenland - Repercussions in Tort Law and Beyond, Copenhagen Business School Law Research Paper, Series, 2019, pg 19-40.

$14 \quad$ Ibid, pg 7.

15 Art 160 and 161A, Federal Constitution of Malaysia 1957.

16 Art 161A(7), Federal Constitution of Malaysia 1957 Art 161A(6), Federal Constitution of Malaysia 1957

18 Section 3(1), Aboriginal peoples Act of Malaysia of 1954.

19 Larsen, J. N., Fondahl, G., \&amp; Rasmussen, H., Arctic human development report: Regional processes and global linkages, Nordic Council of Ministers, Copenhagen, 2014, pg 85 .

20 Graugaard, N. D, National Identity in Greenland in the Age of Self-Government, Centre for the Critical Study of Political Power and Politics, 2009, pg 1-70.

21 Nuttall, M., Encyclopedia of the Arctic, Routledge, New York, 2005, pg 791.

22 Steinberg, P., Tasch, J., \&amp; Gerhardt, H., Contesting the Arctic: Politics and imaginaries in the circumpolar North, I.B. Tauris, London, 2018, pg 68.

23 Dwyer, H., \&amp; Burgan, M., Inuit history and culture, Gareth Stevens Pub., New York, 2012, pg 11.

24 Ureland, P. S., Language contact across the North Atlantic, Proceedings of the working groups held at University College, Galway (Ireland), August 29 - September 3, 1992 and the University of Göteborg (Sweden), August 16-21, 1993, Niemeyer, Tübingen, pg 125.

25 Skutsch, C., Encyclopedia of the world's minorities, Routledge, New York, 2005, pg 629.

26 Mamo, D. (ed), The Indigenous world, 34th ed., 2020, pg 518.

27 Schedule. Greenland Home Rule Act of 1979.

28 Nordin, R., Rights of the indigenous peoples in Peninsular Malaysia: domestic and international perspectives, 2018, pg 33 .

29 Ureland, P. S., Language contact across the North Atlantic, Proceedings of the working groups held at University College, Galway (Ireland), August 29 - September 3, 1992 and the University of Göteborg (Sweden), August 16-21, 1993, Niemeyer, Tübingen, pg 127.

30 Ibid.

31 Ulfbeck, V., Møllmann, A., Mortensen, B. O., Responsibilities and liabilities for commercial activity in the Arctic: The example of Greenland,pg 12.

32 Ibid.

33 Parliament's composition. Danish Parliament website, Retrieved June 14, 2020, from https://www.thedanish parliament.dk/en/democracy/parliaments-composition

34 Politics in Greenland. (n.d.), Retrieved June 11, 2020, from https://naalakkersuisut.gl/en/About-government-ofgreenland/About-Greenland/Politics-in-Greenland

35 Foighel, I., Home rule in Greenland, Nyt Nordisk Forlag, Cph, 1980, pg 3. 
36 Ibid.

37 Chapter 2 and Schedule. Greenland Home Rule Act of 1979 .

38 Chapter 1, Section 1 and 2. Greenland Home Rule Act of 1979.

39 Chapter 3. Greenland Home Rule Act of 1979.

40 Politics in Greenland. (n.d.). Retrieved June 14, 2020, from https://naalakkersuisut.gl/en/About-government-ofgreenland/About-Greenland/Politics-in-Greenland

$41 \quad$ Section 23. Greenland Self-Government Act of 2009.

42 Preamble and Chapter 7. Greenland Self-Government Act of 2009.

43 Chapter 1. Greenland Self-Government Act of 2009.

44 Chapter 3. Greenland Self-Government Act of 2009.

45 Takahashi, M., The Politics of the Right to SelfDetermination: Reframing the Debate on Greenland's Autonomy, Eurasia Border Review, 6(1), 2016, pg 25-43.

46 Ibp, I., Greenland Economic and Development Strategy Handbook - Strategic Information, Regulations Opportunities, 6th ed., International Business Publications, USA, 2018, pg 131

47 Chapter 3. Greenland Self-Government Act of 2009.

48 Chapter 8. Greenland Self-Government Act of 2009.

49 Chapter 1. Greenland Self-Government Act of 2009.

50 Mortensen, B., \& Barten, U., The Greenland SelfGovernment Act: The Pitfall for the Inuit in Greenland to Remain an Indigenous peoples, Yearbook of Polar Law, 8, 2016, pg 103-128.

51 Lennox, C., \&amp; Short, D., Handbook of indigenous peoples'rights, Routledge, London, 2018, pg 431.

52 Dessanti, C., Indigenous peoples' Right to SelfDetermination, Intra Vires 1.1, 2015, pg 45-55.

53 The United Nations General Assembly, United Nations Declaration on the Rights of Indigenous peoples (A/61/L.67 and Add.1), Article 4, 2007.

54 Dessanti, C.. Indigenous peoples' Right to SelfDetermination, pg 48.

55 Seymour, M., Internal Self-Determination and Secession In Pavkovic, A. et.al. (eds.), The Ashgate Research Companion to Secession, Ashgate, Fanham, Burlington, 2011, pg 385-397.

56 Ulfbeck, V., Møllmann, A., Mortensen, B. O.. Responsibilities and liabilities for commercial activity in the Arctic: The example of Greenland.

57 Rasheed, A., Iraqi court rules Kurdish independence vote unconstitutional, Retrieved July 06, 2020, from https:// www.reuters.com/article/us-mideast-crisis-iraq-kurdsidUSKBN1DK0Q6

58 Nordin, R., \& Witbrodt, M. A., Self-Determination of Indigenous peoples: The Case of the Orang Asli, Asia Pacific Law Review, 20(2), 2012, pg 189-210.

59 Nordin, R., \& Witbrodt, M. A.. Self-Determination of Indigenous peoples: The Case of the Orang Asli, pg 202.

60 Section 16(1). Aboriginal peoples Act of Malaysia (1954)

61 Section 3(3). Aboriginal peoples Act of Malaysia (1954)

62 Nordin, R., \& Witbrodt, M. A., Self-Determination of Indigenous peoples: The Case of the Orang Asli, pg 202.

63 Nordin, R., \& Witbrodt, M. A., Self-Determination of Indigenous peoples: The Case of the Orang Asli, pg 204.

64 Ibid.

65 UN Human Rights Council, Report of the Special Rapporteur on the rights of indigenous people. UN General Assembly. A/HRC/42/37/Add.2, 2019.
66 Ibid.

67 Atlas of languages in danger: United Nations Educational, Scientific and Cultural Organization. (n.d.). Retrieved June 22, 2020, from http://www.unesco.org/new/en/culture/ themes/endangered-languages/atlas-of-languages-indanger/

\section{REFERENCES}

Aboriginal Peoples Act of Malaysia. 1954.

Cobo, J. M. 1987. Study of the Problem of Discrimination Against Indigenous Populations: Final Report E/CN.4/ Sub.2/1986/7/Add.4. New York: United Nations.

Cultural Survival. 2015. Observations on the State of Indigenous Human Rights in Denmark in Light of the UN Declaration on the Rights of Indigenous Peoples Denmark.

Danish Parliament website. Parliament's composition. Retrieved June 14, 2020, from.https://www. thedanishparliament.dk/en/democracy/parliamentscomposition

Dessanti, C. 2015. Indigenous peoples' right to selfdetermination. Intra Vires 1.1: 45-55.

Dwyer, H., \&amp; Burgan, M. 2012. Inuit history and culture. New York: Gareth Stevens Pub.

Edited by Mamo, D. 2020. The Indigenous world. 34th ed. Copenhagen, International Work Group for Indigenous Affairs (IWGIA)

Federal Constitution of Malaysia. 1957.

Foighel, I. 1980. Home rule in Greenland. Cph.: Nyt Nordisk Forlag.

Freeman, M. M. 2000. Endangered peoples of the Arctic: Struggles to survive and thrive. London: Greenwood Press.

Graugaard, N. D. 2009. National Identity in Greenland in the Age of Self-Government. Centre for the Critical Study of Political Power and Politics. 1-70.

Holle, M. L. 2019. The Forced Relocation of Indigenous Peoples in Greenland - Repercussions in Tort Law and Beyond. Copenhagen Business School Law Research Paper. Series 19-40.

Home Rule Act of Greenland. 1979

Ibp, I. 2018. Greenland Economic and Development Strategy Handbook - Strategic Information, Regulations Opportunities. $6^{\text {th }}$ edition. USA: International Business Publications.

Larsen, J. N., Fondahl, G., \&amp; Rasmussen, H. 2014. Arctic human development report: Regional processes and global linkages. Copenhagen, Nordic Council of Ministers

Lennox, C., \& Short, D. 2018. Handbook of Indigenous Peoples'Rights. London: Routledge.

Mortensen, B., \& Barten, U. 2016. The Greenland SelfGovernment Act: The Pitfall for the Inuit in Greenland to Remain an Indigenous People. Yearbook of Polar Law. 8,103-128.

Nordin, R., \& Witbrodt, M. A. 2012. Self-determination of indigenous peoples: The case of the Orang Asli. Asia Pacific Law Review 20(2): 189-210.

Nordin, R. 2018. Rights of the indigenous peoples in Peninsular Malaysia: Domestic and international perspectives. Bangi: Penerbit Universiti Kebangsaan Malaysia 
Nuttall, M. 2005. Encyclopedia of the Arctic. New York: Routledge.

Politics in Greenland. (n.d.). Retrieved June 11, 2020 , from https://naalakkersuisut.gl/en/About-governmentof-greenland/About-Greenland/Politics-in-Greenland

Rasheed, A. 2017. Iraqi court rules Kurdish independence vote unconstitutional. Retrieved July 06, 2020, from https://www.reuters.com/article/us-mideast-crisis-iraqkurds-idUSKBN1DK0Q6

Self-Government Act of Greenland. 2009

Seymour, M. 2011. Internal Self-Determination and Secession. In The Ashgate Research Companion to Secession, edited by Pavkovic, A. et al., 385-397. Fanham, Burlington: Ashgate.

Skutsch, C. 2005. Encyclopedia of the World's Minorities. New York: Routledge

Steinberg, P., Tasch, J., \&amp; Gerhardt, H. 2018. Contesting the Arctic: Politics and Imaginaries in the Circumpolar North. London: I.B. Tauris.

Spiermann, O. 2004. Hingitaq 53, Qajutaq Petersen, and Others v. Prime Minister's Office (Qaanaaq Municipality and Greenland Home Rule Government Intervening in Support of the Appellants). The American Journal of International Law. 98(3), 572.

Takahashi, M. 2016. The Politics of the Right to SelfDetermination: Reframing the Debate on Greenland's Autonomy. Eurasia Border Review. 6(1), 25-43.

The United Nations General Assembly. 1966. International Covenant on Civil and Political Rights. Treaty Series, 999, 171.
The United Nations General Assembly. 2007. United Nations Declaration on the Rights of Indigenous Peoples (A/61/L.67 and Add.1).

Ulfbeck, V., Møllmann, A., Mortensen, B. O. 2018. Responsibilities and liabilities for commercial activity in the Arctic: The example of Greenland. Milton Park, Abington, Oxon, United ${ }^{1}$ Kingdom, Routledge, Taylor \&amp; Francis Group.

UN Human Rights Council 2019. Report of the Special Rapporteur on the Rights of Indigenous People. UN General Assembly. A/HRC/42/37/Add.2

Ureland, P. S. 1996. Language contact across the North Atlantic: Proceedings of the working groups held at University College, Galway (Ireland), August 29 September 3, 1992 and the University of Göteborg (Sweden), August 16-21, 1993. Tübingen: Niemeyer.

Hashimah binti Abdul Halim

LLM Graduate

Faculty of Law

Universiti Kebangsaan Malaysia

Email: p98844@siswa.ukm.edu.my

Rohaida Nordin (Corresponding Author)

Lecturer

Faculty of Law

Universiti Kebangsaan Malaysia

Email: rohaidanordin@ukm.edu.my 